\title{
MEMBINA KEBUGARAN JASMANI ANAK DENGAN SENAM PEMBENTUKAN
}

\author{
Oleh: Fredericus Suharjana \\ Dosen Jurusan Pendidikan Olahraga dan Rekreasi FIK-UNY
}

Abstrak:

Kebugaran jasmani merupakan kemampuan seseorang untuk melakukan aktivitas sehari-hari tanpa mengalami kelelahan yang berlebihan dan masih memiliki cadangan tenaga yang dapat dipergunakan secara mendadak atau mengisi waktu luang. Kebugaran jasmani perlu dibina sejak kecil, secara formal mulai anak sekolah dasar (SD), terutama untuk keperluan aktivitas bermain serta membantu pertumbuhan dan perkembangan anak.

Senam pembentukan merupakan alat yang sesuai untuk membina sikap dan gerak dasar, sehingga unsur-unsur kemampuan fisik meningkat, yang selanjutnya kebugaran jasmani anak meningkat pula. Metode latihan senam pembentukan adalah: A. Pemanasan; B. Latihan Inti, yang terdiri atas latihan: (1) normalisasi (pelemasan, penguluran, penguatan, dan pelepasan), (2) keseimbangan, (3) kekuatan dan ketangkasan, (4) jalan dan lari, serta (5) lompat dan loncat; C. Pendinginan. Dalam senam pembentukan, hampir semua komponen kebugaran jasmani dibentuk dan dikembangkan, seperti: daya tahan kardiorespirasi, kelentukan, kecepatan, kekuatan otot, daya tahan otot, keseimbangan, power, kelincahan, koordinasi, dan kecepatan reaksi.

Membina kebugaran jasmani anak perlu memperhatikan prinsip-prinsip latihan, yaitu: overload (beben latihan selalu meningkat), frekwensi (banyaknya latihan dalam satu minggu), intensitas (seberapa berat seseorang berlatih selama periode latihan), waktu (lamanya latihan dilaksanakan), dan tipe (kekhasan dari bentuk latihan yang dilakukan).

Kata Kunci: kebugaran jasmani, senam pembentukan

Semua orang sangat mendambakan kesehatan dirinya dan berupaya dengan berbagai cara, agar tubuhnya selalu dalam keadaan sehat dan bugar. Kesehatan dan kebugaran jasmani merupakan harta yang tak ternilai harganya bagi kehidupan manusia. Kita tidak akan dapat melakukan aktivitas sehari-hari dengan baik apabila badan titak dalam keadaan sehat dan bugar. 
Bagi anak, kebugaran jasmani sangat diperlukan dalam membantu pertumbuhan dan perkembangannya. Kehidupan anak sehari-hari waktunya banyak dipergunakan untuk aktivitas bermain, sangat diperlukan tubuh yang sehat dan bugar. Anak yang tidak sehat dan bugar biasanya disebabkan karena kurang gerak. Menyadari hal itu, maka perlu diupayakan suatu cara untuk membantu bagaimana agar anak selalu dalam keadaan sehat dan bugar. Salah satu cara yaitu dengan membiasakan anak untuk melakukan aktivitas fisik atau berolahraga.

Pendidikan jasmani, olahraga, dan kesehatan yang dilaksanakan di sekolah-sekolah merupakan suatu alat yang tepat untuk membina dan mengembangkan kesehatan dan kebugaran jasmani anak. Salah satu aktivitas yang sangat membantu untuk membina kebugaran jasmani anak, yaitu dengan senam pembentukan. Melalui senam pembentukan anak akan dibentuk sikap dan gerak dasarnya, sehinga unsur-unsur kemampuan sikap dan gerak dasar anak akan berkembang, sehingga kemampuan fisiknya meningkat, yang selanjutnya kebugaran jasmaninya juga meningkat.

\section{KEBUGARAN JASMANI}

Kebugaran jasmani (physical fitness) yang memadahi merupakan keadaan yang sangat didambakan oleh setiap orang. Dengan memiliki kesegaran jasmani yang baik, seseorang sangat dimungkinkan akan dapat melakukan kegiatan sehari-hari tanpa timbul kelelahan yang berarti. Bagi para pekerja, mereka dapat bekerja sesuai dengan tuntutan pekerjaannya. Bagi anak, kebugaran jasmani akan sangat bermanfaat untuk dapat tumbuh dan berkembang, serta menuaikan tugas sehari-hari, seperti bermain dan belajar. Djoko Pekik Irianto (2004: 2) menyatakan bahwa secara umum yang dimaksud dengan kebugaran adalah kebugaran fisik (physical fitness), yakni kemampuan seseorang melakukan kerja sehari-hari secara efisien tanpa menimbulkan kelelahan yang berlebihan, sehingga masih dapat menikmati waktu luangnya. Menurut Howley dan Franks (1992: 24) kebugaran jasmani merupakan kemampuan fisik untuk bekerja secara optimal, serta mengurangi rIsiko terhadap masalah kesehatan. Pendapat lain mengatakan bahwa kebugaran jasmani adalah kemampuan seseorang menyelesaikan tugas sehari-hari dengan tanpa mengalami kelelahan berarti, dengan mengeluarkan energi yang cukup besar, guna memenuhi kebutuhan geraknya dan menikmati waktu luang, serta untuk memenuhi keperluan darurat apabila sewaktu-waktu diperlukan (Mochamad Sajoto, 1988: 34). Menurut Iskandar dkk. (1999: 4) kebugaran jasmani pada hakikatnya berkenaan dengan kondisi fisik seseorang dalam melaksanakan tugas sehari-hari secara efisien dan waktu yang relatif lama tanpa kelelahan yang berarti dan masih memiliki cadangan tenaga untuk melaksanakan aktivitas lainnya.

Dari beberapa pendapat di atas dapat disimpulkan bahwa kebugaran jasmani adalah kualitas seseorang untuk melakukan aktivitas sesuai pekerjaannya secara optimal tanpa menimbulkan problem kesehatan dan kelelahan berlebihan.

MIEDIKORA Vol. VII, No. 1, April 2011: 77 - 86 
Kebugaran jasmani terdiri atas beberapa komponen yang masing-masing saling berkaitan serta saling mempengaruhi satu dengan yang lainnya. Rusli Lutan, dkk. (2001: 8) menyatakan bahwa komponen kebugaran jasmani terdiri atas: (1) Kebugaran jasmani yang berkaitan dengan kesehatan, mengandung unsur-unsur: kekuatan otot, daya tahan otot, daya tahan aerobik, dan fleksibilitas. (2) Kebugaran jasmani yang berkaitan dengan performance, mengandung unsur-unsur: koordinasi, kelincahan, kecepatan gerak, dan keseimbangan.

Sudarno (1991: 21) menyatakan bahwa komponen-komponen kebugaran jasmani terdiri atas: kesehatan yang baik, kekuatan, kelincahan, ketahanan otot, kecepatan, keseimbangan, kelentukan, koordinasi, ketahanan kardiorespiratori, berat badan yang sesuai, kemampuan motorik umum, serta ketangkasan neuromuscular, sedangkan Dangsina Moeloek (1984: 3) menyatakan bahwa unsur-unsur kebugaran jasmani meliputi: daya tahan (endurance), kekuatan otot (muscle strength), tenaga ledak otot (muscle explosive power), kecepatan (speed), ketangkasan (agility), kelenturan (flexibility), keseimbangan (balance), kecepatan reaksi (reaction time), dan koordinasi (coordination).

Seseorang dapat dikatakan memiliki status kebugaran jasmani yang baik, kalau seseorang tersebut memenuhi derajat kebugaran yang baik menurut parameter tertentu. Salah satu parameter yang dapat dugunakan untuk menentukan derajat kebugaran jasmani anak adalah Tes Kesegaran/Kebugaran Jasmani Indonesia (TKJI) yang terdiri atas lima butir tes, yaitu: (1) lari cepat 30/40 meter, untuk mengukur kecepatan, (2) gantung siku tekuk, untuk mengukur kekuatan dan daya tahan otot-otot lengan dan bahu, (3) baring duduk 30 detik, untuk mengukur kekuatan dan daya tahan otot-otot perut, (4) loncat tegak, untuk mengukur daya ledak, dan (5) lari 600/800 meter, untuk mengukur daya tahan kardiorespirasi.

Untuk mendapatkan kesehatan dan kebugaran jasmani yang baik, seseorang harus berpola hidup sehat (quality of life). Menurut Sharkey (2003: 30) untuk mencapai "quality of life" tersebut ada tiga aspek yang harus dipenuhi, yaitu: mengatur makanan, mengatur waktu istirahat, dan melakukan aktivitas (berolahraga).

Mengatur pola makanan. Untuk melakukan aktivitas sehari-hari manusia memerlukan energi. Energi tersebut diperoleh dari makanan yang dikonsumsi sehari-hari. Proporsi makanan yang baik adalah: karbohidrat $60 \%$, lemak $25 \%$, dan protein $15 \%$.

Mengatur waktu istirahat. Istirahat diperlukan manusia untuk memberikan recovery terhadap aktivitas faali tubuh, sehingga tubuh dapat melakukan kerja sehari-hari dengan baik. Istirahat digunakan tubuh untuk membuang asam laktat, sehingga tubuh bisa bugar kembali.

Melakukan aktivitas (berolahraga). Dengan berolahraga secara terprogram, teratur dan terukur, seseorang akan mencapai tingkat kebugaran jasmani yang baik. Jika kebugaran jasmani seseorang baik, maka harapannya orang tersebut juga akan memiliki derajat kesehatan yang baik pula. 


\section{SENAM}

Imam Hidayat (1982: 2) menyatakan bahwa secara umum senam dapat diartikan suatu latihan tubuh yang dipilih dan diciptakan dengan sengaja dan berencana, disusun secara sistematis dengan tujuan membentuk dan mengembangkan pribadi secara harmonis. Lebih lanjut Agus Mahendra (2001: 2) menyatakan bahwa senam sebagai suatu latihan tubuh yang dipilih dan dikonstruk dengan sengaja, dilakukan secara sadar dan terencana, disusun sesara sistematis dengan tujuan meningkatkan kesegaran jasmani, mengembangkan keterampilan, dan menanamkan nilai-nilai mental spiritual.

Dewasa ini banyak sekali bermunculan macam-macam nama senam, seperti: senam pagi, senam kesegaran jasmani, senam jantung sehat, senam lansia, senam otak, dan lainlain. Setiap macam atau nama dari senam tersebut, tentu latihan atau gerakan-gerakannya memang sengaja dibuat, kemudian disusun secara sistematik, serta mempunyai tujuan tertentu. Masing-masing senam memiliki ciri-ciri gerakan sendiri serta tujuannya disesuaikan dengan namanya. Misalnya, senam si buyung dengan ciri-ciri gerakan meniru, tujuannya untuk memenuhi hasrat bergerak anak kecil.

Mengingat banyaknya macam senam, maka Federasi Senam Internasional yaitu Federation Internationale de Gymnastique (FIG) mengelompokkan senam menjadi enam, yaitu:

1. Senam Artistik (Artistic Gymnastics) adalah gerakan yang cepat dan eksplosif, pada umumnya menonjolkan kelentukan dan keseimbangan, dan dilakukan dengan gerakan yang agak lambat, dilaksanakan secara terkontrol yang mampu memberikan pengaruh mengejutkan dan mengundang rasa keindahan.

2. Senam Ritmik Sportif (Sportive Rhytmic Gymnastics) adalah senam yang komposisi geraknya diantarkan oleh tuntunan irama musik, yang menghasilkan gerak-gerak tubuh dan alat yang indah.

3. Senam Akrobatik (Acrobatic Gymnastics) adalah senam yang mengandalkan kelentukan dan keseimbangan dengan gerakan yang cepat dan ekslposif, sehingga latihannya banyak mengandung salto dan putaran, sementara pesenamnya harus mendarat di tempat-tempat yang sulit.

4. Senam Aerobik Sport (Sport Aerobics) adalah penggabungan dari gerak tarian, kekuatan, kelentukan dan keseimbangan, sehingga pantas diperlombakan.

5. Senam Trampolin (Trampolinning) adalah pengembangan dari satu bentuk latihan yang dilakukan di atas trampolin, yaitu sejenis alat pantul yang memiliki daya pantul yang sangat besar.

6. Senam Umum (General Gymnastics) adalah segala jenis senam di luar kelima jenis senam tersebut di atas.

\section{SENAM PEMBENTUKAN}

Senam pembentukan atau disebut juga senam dasar adalah latihan tubuh yang dipilih dan diciptakan dengan sengaja dan berencana, disusun secara sistematis dan metodis, 
dengan tujuan untuk membentuk tubuh. Tubuh anak perlu dibentuk sikap dan gerak dasarnya lebih dahulu, agar tubuh selalu dalam keadaan sikap yang benar. Pengertian sikap yaitu sikap tubuh dalam keadaan diam maupun dalam keadaan bergerak. Sikap tubuh dalam keadaan diam, seperti berbagai sikap berdiri, jongkok, duduk, dan berbaring, sedangkan sikap tubuh dalam keadaan bergerak, seperti berjalan, berlari, melompat, meloncat, memukul, dan menyepak.

Menurut Sumanto dan Sukiyo (1991: 127) salah satu fungsi senam pembentukan adalah mengupayakan agar tubuh tetap berada dalam keadaan sikap yang benar, dan jika terjadi sikap tubuh yang salah, harus segera memperbaikinya, sehingga menjadi benar. Lebih lanjut Sumanto dan Sukiyo (1991: 128) menyatakan bahwa beberapa kemungkinan yang dapat menyebabkan terjadinya sikap tubuh yang salah antara lain:

1. Pembawaan sejak lahir.

2. Kurang atau tidak terpenuhinya zat-zat makanan.

3. Penyakit atau kecelakaan.

4. Kelemahan otot-otot tubuh.

5. Kelemahan tulang-tulang kerangka.

6. Kebiasaan yang salah.

Kesalahan terhadap sikap tubuh yang disebabkan oleh kemungkinan-kemungkinan tersebut antara lain:

1. Kiposis, yaitu bentuk kesalahan tubuh yang disebabkan karena adanya penonjolan lengkung tulang belakang bagian punggung. Jika tulang belakang bagian punggung membungkuk, maka bagian depan susunan tulang belakang menjadi berbentuk cekung. 2. Lordosis, yaitu bentuk kesalahan tubuh yang disebabkan oleh adanya penonjolan bagian tulang belakang di daerah lumbal, daerah pinggang, sehingga daerah belakang susunan tulang belakang bagian pinggang mencekung, dan biasanya panggul terdorong ke depan bawah. Keadaan yang demikian menyebabkan otot daerah pinggang bagian belakang terlihat memendek.

3. Skoliosis, yaitu bentuk kesalahan tubuh yang disebabkan oleh adanya penyimpangan susunan tulang belakang. Jika penyimpangan tersebut dilihat dari arah belakang, tonjolan-tonjolan susunan tulang belakang tidak berada dalam satu garis lurus. Penyimpangan dapat terjadi ke kiri atau ke kanan, ke arah punggung atau ke arah pinggang.

Usaha preventif yang dapat dilakukan agar anak terhindar dari kesalahan-kesalahan sikap dan gerak dasar tubuh adalah dengan membiasakan anak-anak untuk senantiasa melakukan sikap dan gerak yang benar. Perlu diwaspadai kebiasaan anak terutama di lingkungan sekolah yang dapat mempunyai pengaruh yang tidak baik bagi sikap tubuh, seperti kebiasaan duduk yang salah selama mengikuti pelajaran di dalam kelas, atau kebiasaan dalam membawa tas sekolah, yang dapat memungkinkan anak memiliki sikap tubuh kiposis, lordosis, atau skoliosis. 
Sumanto dan Sukiyo (1991: 131) menyatakan bahwa menanamkan sikap tubuh yang benar dengan pembiasaan diri selama anak-anak masih dalam taraf pertumbuhan mempunyai pengaruh dan manfaat sangat besar bagi hidupnya di masa depan, seperti:

1. Membantu pertumbuhan anak ke arah yang seharusnya

2. Mencegah kesalahan bentuk dan sikap tubuh

3. Mencegah kebiasaan yang tidak seharusnya

4. Menghayati arti pentingnya menguasai sikap dan gerak tubuh yang seharusnya.

Jika anak sudah memiliki sikap dan gerak dasar tubuh yang benar, selanjutnya akan lebih mudah dalam mengembangkan berbagai macam kemampuan tubuh, seperti keseimbangan, kelentukan, kekuatan otot, daya tahan otot, kecepatan, kelincahan, koordinasi, power, dan kecepatan reaksi.

\section{METODE LATIHAN SENAM PEMBENTUKAN}

Sebagai salah satu usaha agar latihan senam pembentukan yang dilakukan dapat mencapai hasil yang optimal, kebanyakan orang menggunakan sistematika yang dikembangkan oleh Gaulhofer dan Streicher yang kemudian dikenal dengan system Austria. Adapun susunan latihannya terdiri atas:

A. Pemanasan

B. Latihan Inti, yang terdiri atas:

B1. Latihan normalisasi,

B2. Latihan keseimbangan,

B3. Latihan kekuatan dan ketangkasan,

B4. Latihan berjalan dan berlari,

B5. Latihan melompat dan meloncat),

C. Penenangan

Penggunaan tenaga yang dipergunakan dalam latihan harus secara berangsur bertambah besar hingga mencapai puncak. Setelah mencapai puncak, pertahankan beberapa saat, kemudian berangsur turun kembali. Jika pemakaian tenaga itu digambarkan dengan suatu grafik, maka garis dalam grafik itu akan merupakan suatu kurve pada gambar sebagai berikut:

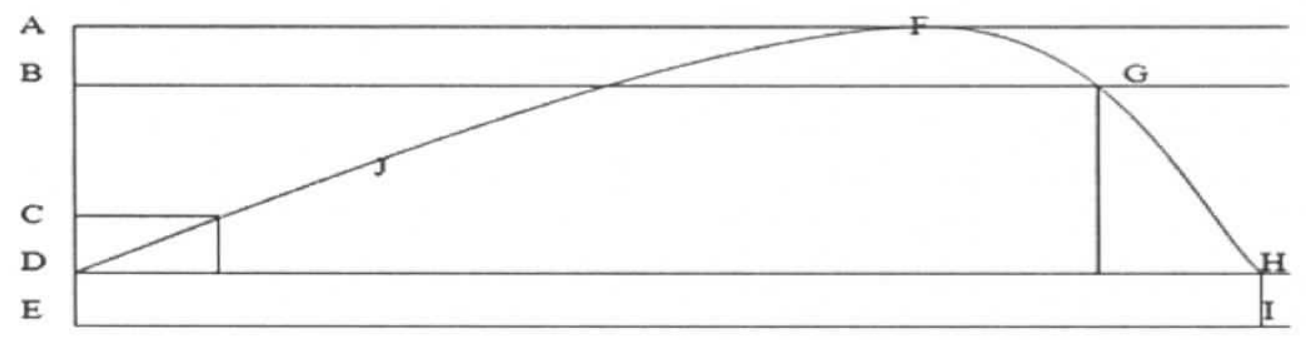

Gambar 1. Kurve Penggunaan Tenaga dalam Latihan Senam Pembentukan. 
1. E ke arah A : Banyaknya tenaga yang dipergunakan oleh tubuh, makin naik berarti makin besar.

2. E ke arah I : Banyaknya waktu yang diperlukan.

3. ED H I : Tenaga yang biasa dipergunakan dalam hidup sehari-hari.

4. DJ : Bagian pemanasan.

5. JFG : Bagian inti.

6. GH : Bagian penenangan.

\section{A. Pemanasan}

Pemanasan mutlak diperlukan dalam mengawali latihan senam pembentukan untuk mempersiapkan jiwa dan raga anak dalam melakukan latihan inti, agar mendapatkan manfaat yang sebesar-besarnya tanpa mengalami bahaya. Persyaratan yang harus diperhatikan dalam pemanasan adalah: memenuhi keinginan bergerak, menaikkan suhu tubuh, waktu tidak lama, serta tidak melelahkan.

Aktivitas pemanasan dapat dilakukan dengan berbagai bentuk, seperti:

1. Permainan

2. Perlombaan

3. Reaksi

4. Jalan, lari, jengket-jengket, loncat-loncat, lompat-lompat, serta variasinya.

\section{B. Latihan Inti}

B1. Latihan Normalisasi

Latihan normalisasi bertujuan untuk memperbaiki atau membetulkan kesalahankesalahan ringan yang terdapat pada anak. Kesalahan-kesalahan yang ringan pada anak dapat diperbaiki dengan jalan membiasakan cara bersikap dan bergerak yang wajar atau normal, sehingga akan menghasilkan bentuk tubuh yang wajar pula.

Latihan normalisasi terdiri atas:

a. Latihan pelemasan, yang ditujukan untuk memberikan kemungkinan kelicinan dan keluasan gerak pada persendian-persendian badan.

b. Latihan penguluran, yang ditujukan untuk memperpanjang jaringan-jaringan pengikat, tendo-tendo otot, tali-tali sendi, pembungkus sendi, sehingga tidak mengalami kekakuan otot tetapi otot menjadi elastis.

c. Latihan penguatan, yang ditujukan untuk menguatkan otot-otot setempat yang lemah.

d. Latihan pelepasan, yang ditujukan untuk mempetinggi koordinasi otot dan perasaan gerak.

B2. Latihan Keseimbangan

Latihan keseimbangan bertujuan untuk mempertinggi perasaan keseimbangan dan perasaan kerja otot yang selanjutnya memiliki arti yang besar dalam 
pembentukan sikap, gerak dasar, pengembangan ketangkasan, serta prestasi gerak. B3. Latihan Kekuatan dan Ketangkasan

Latihan kekuatan dan ketangkasan ditujukan untuk mengembangkan kekuatan, kecepatan, keuletan, ketangkasan, yaitu koordinasi antar otot dan kesanggupan untuk secepat mungkin menyesuaikan diri terhadap suatu keadaan, di samping merupakan latihan prestasi yang harus dilakukan dengan gerak yang terkuasai.

B4. Latihan Berjalan dan Berlari

Latihan berjalan dan berlari ditujukan untuk mengembangkan kemampuan organ tubuh (paru-paru, jantung, serta peredaran darah), atau latihan untuk meningkatkan ketahanan, prestasi, penguasaan sikap dan gerak.

B5. Latihan Melompat dan Meloncat

Latihan melompat dan meloncat ditujukan untuk mengembangkan kemampuan meledakkan tenaga, di samping merupakan latihan prestasi, penguasaan sikap gerak serta koordinasi

\section{Penenangan}

Penenangan sangat diperlukan sebagai penutup dari senam pembentukan, dengan tujuan untak menurunkan suhu tubuh dan kerja organ-organ tubuh kembali seperti semula atau normal.

Dalam pelaksanaan latihan senam pembentukan kegiatan dibuat dalam bentuk bermain agar anak senang serta banyak variasinya supaya tidak menjadi bosan.

\section{PRINSIP DASAR LATIHAN}

Pelaksanaan latihan senam pembentukan untuk meningkatkan kebugaran jasmani bagi anak perlu memperhatikan beberapa prinsip, seperti dikemukakan oleh Rusli Lutan (2002: 30-33) bahwa prinsip latihan kebugaran jasmani adalah:

1. Prinsip overload, yang dimaksud adalah beban yang diatasi dalam latihan itu selalu meningkat dan peningkatannya secara bertahap. Peningkatan beban harus berhatihati dan jangan dipaksakan karena dapat membahayakan kesehatan anak. Berikan kesempatan kepada anak untuk berkembang sesuai dengan tempo perkembangannya supaya aman.

2. Prinsip FIWT, yaitu kepanjangan dari:

$\mathbf{F}=$ Frekwensi, yaitu berapa kali orang melakukan latihan dalam satu minggu. Bagi anak, dalam melakukan latihan senam pembentukan untuk memenuhi standard kebugaran tingkat dasar, frekwensi dilakukan sebanyak tiga kali dalam satu minggu. I = Intensitas, yaitu seberapa berat seseorang berlatih selama periode latihan. Bagi anak, intensitas latihan senam pembentukan menggunakan kurve penggunaan tenaga untuk latihan. Diawali pemanasan, dilanjutkan latihan normalisasi (pelemasan, penguluran, penguatan, dan pelepasan), latihan keseimbangan, latihan kekuatan dan ketangkasan, kemudian ditingkatkan latihan jalan dan lari, sampai pada puncak latihan 
lompat dan loncat, kemudian diturunkan secara perlahan dengan pendinginan. $\mathbb{W}=$ Waktu, yaitu lamanya latihan dilaksanakan. Senam pembentukan bagi anak, waktu setiap kali latihan menurut Ismail Umarella (183: 68) selama 45 menit, dengan rincian: (1) Pemanasan 5 menit, (2) Latihan normalisasi 10 menit, (3) Latihan keseimbangan 5 menit, (4) Latihan kekuatan dan ketangkasan 12 menit, (5) Latihan jalan-lari, lompat-loncat 8 menit, dan (6) Pendinginan 5 menit.

$\mathbf{T}=$ Tipe atau kekhasan, yaitu kekhasan dari bentuk latihan yang dilakukan. Senam pembentukan melibackan banyak komponen yang dilatih, namun harus ada penekanan dari setiap kali latihan, komponen kebugaran apa yang akan dilatih.

\section{KESIMPULAN}

Kebugaran jasmani perlu dibina dan dikembangkan mulai anak-anak, karena kebugaran jasmani sangat diperlukan bagi pertumbuhan dan perkembangan anak. Sesuai dengan karakteristik anak bahwa mereka suka bermain, jika fisiknya tidak bugar, maka tidak akan dapat melakukan aktivitas bermain dengan baik. Berbagai aktivitas fisik dapat dipergunakan sebagai alat untuk meningkatkan kebugaran jasmani anak, salah satunya adalah senam pembentukan. Melalui latihan senam pembentukan, anak akan dibentuk dan dikembangkan unsur-unsur kemampuan fisiknya seperti kelentukan, keseimbangan, kekuatan otot, daya tahan otot, power, kecepatan, koordinasi, daya tahan kardiorespirasi, dan lain sebagainya. Jika unsur-unsur kemampuan fisik dapat dibina dan dikembangkan, maka kebugaran jasmani anak akan meningkat, sehingga pertumbuhan dan perkembangan anak tidak mengalami gangguan atau dapat berjalan normal. Pelaksanaan latihan senam pembentukan harus dilakukan sesuai dengan prinsip-prinsip dasar latihan yang meliputi frekwensi, intensitas, waktu, serta tipe latihan.

\section{DAFTAR PUSTAKA}

Agus Mahendra. (2001). Pembelajaran Senam di Dekolah Dasar Sebuab Pendekatan Pembinaan Pola Gerak Dominan. Jakarta: Depdiknas Ditjen Dikdasmen.

Dangsina Moeloek. (1984). Kesehatan dan Olabraga. Jakarta: FKUI.

Djoko Pekik Irianto. (2004). Pedoman Praktis Berolabraga Untuk Kebugaran \& Kesehatan. Yogyakarta: Andi Offset.

Howley, E.T. dan Franks, B.D. (1992). Health Fitness Instruktor's Handbook. South Australia: Kinetics Publisher.Inc.

Imam Hidayat. (1982). Senam dan Metodik. Jakarta: Depdikbud Ditjen Dikdasmen. Ismail Umarella. (1983). Senam dan Metodik. Jakarta: Proyek Pembinaan SGO Jakarta. 
Iskandar dkk. (1999). Kesegaran Jasmani untuk Karyawan. Jakarta: Pusat Pengkajian dan Pengembangan IPTEK Olahraga.

Mochamad Sajoto. (1988). Pembinaan Kondisi Fisik dalam Olabraga. Jakarta: Depdikbud Ditjen Dikti.

Rusli Lutan, dkk. (2001). Pendidikan Kebugaran Jasmani Orientasi Sepanjang Hayat. Jakarta: Ditjen Olahraga.

Rusli Lutan. (2002). Menuju Sehat dan Bugar. Jakarta: Depdiknas Ditjen Dikdasmen.

Sharkey, B.J. (2003). Fitness and Health. Terjemahan Eri Desmarini Nasution. Jakarta: PT Raja Grafindo Persada. 